81'272(497.11)

811.163.41'26

https://doi.org/10.18485/sj.2018.23.1.26

ЈЕЛЕНА М. ФИЛИПОВИЋ ${ }^{*}$

Филолошки факултет

Универзитет у Београду

АНДРИЈАНА С. ЂОРДАН ${ }^{* *}$

Факултет за стране језике

Алфа БК универзитет у Београду
Оригинални научни рад

Примљен: 04. 01. 2018.

Прихваћен: 29. 01. 2018.

\title{
ТЕРМИНОЛОШКА ПОЛИТИКА И ПЛАНИРАЮЕ У СРБИЈИ: ИНТЕРДИСЦИПЛИНАРНИ ПРИСТУП
}

Рад представља резултате инструменталне квалитативне студије случаја која потврђује релевантност интердисциплинарног, хетерархијског приступа развоју терминолошке језичке политике и планирања у Србији. Уводећи принципе језичког лидерства, ауторке нуде нову платформу за јединствени, савремени и временски и просторно утемељен процес креирања, евалуације, складиштења и стандардизације термина различитих професија и научних дисциплина.

Кључне речи: терминолошка политика и планирање, језичко лидерство, менаџмент језика, адаптибилно, омогућавајуће и административно терминолошко лидерство

\footnotetext{
*jelenafbgd@gmail.com

**andrijana.dordan@gmail.com
} 


\section{1. ТЕРМИНОЛОШКА ПОЛИТИКА И ПЛАНИРАњЕ КАО САСТАВНИ ДЕО ОПШТЕ ЈЕЗИЧКЕ ПОЛИТИКЕ И ПЛАНИРАЬА}

Језичка политика и планирање као област научног истраживања датира од друге половине XX века. Прву дефиницију језичког планирањ $а$ дао је Хауген - ,под језичким планирањем подразумевам активност припреме нормативног правописа, граматике и речника, као смерница за говорно и писано изражавање у нехомогеним говорним заједницама. У овој практичној примени језичког знања идемо даље од дескриптивне лингвистике и залазимо у поље где се суд мора доносити у виду избора између доступних језичких облика" (Хауген, 1959: 8, курзив наш) $)^{1}$.

Већ у првој (Хаугеновој) дефиницији језичке политике и планирања истиче се да се ова активност темељи на избору језичких форми, установљеном екстралингвистичким факторима (дакле, на екстралингвистичким критеријумима). У контексту све веће интер- и транс-дисциплинарности савремене лингвистике (Филиповић 2015a; 2016; 2017) с краја 20. и почетка 21. века, језичка политика и планирање јасно се сагледавају као процес у коме лингвистика корелира са другим научним дисциплинама, као и са ширим епистемолошким и друштвено-историјским факторима који утичу на изборе у вези са језичким структурама и формама које користимо у јавној сфери (Сполски, 2009; Филиповић, 2009; Филиповић, 2011; Филиповић, 2016 итд.)

Обједињујући дефиниције језичке политике и планирања које се појављују у већини уџбеника из социолингвистике, закључујемо да се језичка политика и планирање одређује „као организована, циљана и дугорочна активност институција државе на различитим аспектима статуса, форме и домена употребе одређеног језичког варијетета. Статусна политика и планирање бави се одабиром језичког кода који преузима статус званичног језика у датом политичком ентитету/држави. Корпусна политика и планирање укључује нормирање језичких форми и лексике одабраног званичног језика, док се образовна језичка политика и планирање бави одабиром језика који ће се користити као језици образовања, односно као додатни/други/страни језици у датом образовном систему [...]" (Филиповић, 2009: 54). Такође, уводимо концепт терминолошке политике и планирања као саставни део сваке одговорне корпусне језичке политике која развија терминолошке системе професија и наука у датом језику, обезбеђујући недвосмислену интрајезичку и интерјезичку професионалну и научну комуникацију, формирање информатизованих система за складиштење, даљу примену и трансфер знања, односно прецизно и делотворно стручно писано и усмено превођење. Коначно, морамо имати у виду да горе наведене дефиниције нису свеобухватне, већ да се језичка по-

\footnotetext{
${ }^{1}$ Сви преводи у тексту су дело ауторског рада.
} 
литика и планирање може обављати и изван институција државе, уз примену различитих теоријских постулата и методолошких поступака. Другим речима, можемо разликовати језичку политику „одозго-надоле” (енгл. top-down), која се најчешће повезује са горе наведеном дефиницијом, и језичку политику „одоздо-нагоре" (енгл. bottom-up), која одговара на комуникативне, професионалне и социјално-психолошке потребе говорница и говорника заинтересованих друштвених група односно делатних заједница.

И статусна и корпусна језичка политика и планирање се у ширем европском, па тако и у српском контексту повезују са епистемолошким моделом модерне науке с краја 18. века (канонизованих научних оквира по којима се управљају институције такозваног Западног света, в. Филиповић, 2015a за детаљнију разраду), односно са концептом модерности (Бауман и Бригс, 2003), који стандардни језик ставља у фокус процеса „цивилизације” и приступа јавној сфери комуникације: „само они који говоре „правилно” (они који на располагању имају кодификоване, стандардизоване језичке варијетете са развијеном ортографијом) (...) имају права приступа јавним комуникативним праксама и процесу одлучивања ${ }^{2}$ (Филиповић, 2015a: 12). Другим речима, стандардни језик је заправо друштвенополитички, али и научни конструкт који резултира развојем стандарднојезичких култура (Милрој, 2001; Филиповић, 2009; 2012; 2015а) које не остављају много простора за језичко планирање „одоздо-нагоре”, осетљиво на друштвене, научне, политичке и друге промене у културним моделима дате говорне заједнице (Филиповић, 2015a: 47). У исто време, модерност доноси и привилеговани статус научној елити која кроз специфичне идеологије и политике знања и науке намеће (некада оправдано, некада не) своје ставове и закључке као једине могуће. У случају терминолошке језичке политике и планирања, као што овај рад доказује, идеологије знања појединачних професија и наука не препознају значај и потребу интердисциплинарног умрежавања и намећу недовољно разрађена терминолошка решења. У контексту глобализације научних достигнућа и потребе за афирмисањем српске науке на светској академској сцени, парцијализована активност званично препознатих језичких планера (лингвиста) са једне стране, и чланова професионалних делатних заједница са друге стране, неретко резултира нетранспарентношћу и неадекватношћу српских термина при преводу на друге језике, пре свега на енглески као глобални језик академске комуникације (Филиповић, 2015б).

Дакле, терминолошка политика и планирање, као део корпусне језичке политике и планирања, мора се базирати на свесним и промишљеним изборима термина, заснованим на научним, социокултурним, економским, индустријс-

\footnotetext{
2"Only those who speak the 'proper' language (those who have at their disposal codified, standardized linguistic varieties with developed alphabets (...) are allowed to engage in public practices and decision making"
} 
ким, географским, демографским, психо-социјалним и другим принципима (UNESCO, 2005). Таква врста активности неминовно је интердисциплинарна и захтев комбиновање различитих аспеката знања: 1. онтолошко и знање преточено у тврдње (енгл. ontological and assertional knowledge) (Ван Дигелен и др., 2004), 2. дефиницијско знање и 3. терминолошко знање (Елкин \& Браун, 2012). Управо су онтолошко и знање преточено у тврње критични за формирање научнометодолошких смерница и пракси терминолошке језичке политике: „Онтологија описује поглед на свет датог аутора (у нашем тумачењу, ауторову научну, професионалну, али и личну идеологију, прим. ауторки). База тврдњи о онтолошком знању формира се на основу онтолошких концепата. Сходно томе, успешно представљање ствари из актуелног света директно је зависно од концепата дефинисаних у онтологији. (...) С обзиром на чињеницу да је база знања преточеног у тврдње зависна од онтологије, комуникативне тврдње постају проблематичне када у контакт доводимо хетерогене онтологије (у нашем тумачењу, ради се о политикама знања различитих аутора (прим. ауторки)" (Ван Дигелен и др., 2004: 78).

Другим речима, терминолошка политика и планирање мора у обзир узети различите идеологије и политике знања са једне стране (у којима често лични, афективни фактори аутора и ауторки играју улогу подједнако значајну као и професионално или научно знање), односно практичне, комуникацијски условљене аспекте формирања термина са друге стране (дефиницијско и терминолошко знање) $)^{3}$, а све то у циљу развијања и иновирања система знања у контексту образовних, професионалних и научних активности. У том контексту, као што наше истраживање указује, стандарднојезичка култура представља један од кључних сегмената вредносних система креатора терминолошке језичке политике без обзира na to да ли они припадају корпусу лингвиста или стручњака из различитих научних и професионалних области. У исто време глобализација неминовно захтева и локализацију, односно прилагођавање ло-

${ }^{3}$ Поједностављено представљено, ова тврдња односи се на ситуације када одређени аутор или ауторка употреби лексему или синтагму као термин (знање преточено у тврдње) не узимајући у обзир различите групације публике којима се обраћа, намећући сопствено онтолошко знање, које може бити супротстављено онтолошким знањима других дисциплина. Рецимо, у самој терминолошкој науци наилазимо на један такав проблем. Енглески термин human language technology, "технологија људског језика", лингвистима који се не баве терминолошким студијама свакако звучи редундантно, јер се у лингвистици језик дефинише као разликовна одлика управо људског рода у односу на све остале системе комуникације како међу људима тако и у животињском свету. Дакле, из перспективе лингвистике много би "природније" било користити термин језичке технологије, а уз све остале вештачке језике додати одговарајуће атрибуте (информатички, компјутерски итд.). Међутим, узмемо ли у обзир комуникативне потребе других професионалних делатних заједница у којима се овај термин одомаћио (рецимо, постоји читав низ академских програма на мастер и докторским студијама великог броја универзитета под тим називом), отвара се простор за компромис и интердисциплинарно тумачење у коме би се и даље користио за нас релативно редундантан термин „технологија људског језика”. 
калним културним и језичким нормама свих горе наведених аспеката друштва знања кроз превођење и адаптацију, што такође стоји у директној спрези са терминолошком језичком политиком и планирањем (UNESCO, 2005: ii).

\section{2. СТАНДАРДИЗАЦИЈА КАО ПРЕДУСЛОВ ТЕРМИНОЛОШКЕ ЈЕЗИЧКЕ ПОЛИТИКЕ}

Један од кључних предуслова ваљане терминолошке језичке политике свакако је и стандардизација терминологије.

Према Закону о стандардизацији Републике Србије из 2009. године (измењен и допуњен 2015) ${ }^{4}$, стандардизација је скуп координираних активности на доношењу стандарда и сродних докумената. Јакић (2014: 47) дефинише стандардизацију као „делатност која тражи и налази решења понављајућих задатака у области науке, технике и економије, усмерена на достизање оптималног степена уређености у одређеној области".

Процес стандардизације терминологије је сложен и обухвата одређивање значења термина путем дефиниције, локализацију појма у систему појмова (путем логичких и онтолошких односа међу појмовима), елиминацију хомонимије (или бар свођење на најмању могућу меру), учвршћивање ознака (укључујући и скраћенице и симболе), као и стварање нових термина. Приликом стандардизације терминологије требало би имати на уму социолингвистичке (употребу, језичку политику, потребе корисника, итд.), психолингвистичке (навике, естетичке и етичке елементе, инхибиције итд.) и формалне језичке критеријуме (начин стварања термина, деривациони потенцијал итд.).

Заправо, ако се има у виду да је језичка стандардизација не само лингвистички, већ и шири социокултурни, па и цивилизацијски процес, ни стандардизација терминологије не може бити активност једне дисциплине, већ искључиво интердисциплинарни задатак.

Стандардолошки изазови на пољу терминологије у српском језику су бројни. Један од највидљивијих свакако је продор енглеског језика као глобалне лингва франке (lingua franca) у све поре људског деловања. Заузимајући тако моћну позицију, енглески језик постао је „главни лексички давалац” (Силашки 2012: 11) осталим европским језицима (додале бисмо и терминолошки), како у општем, тако и у регистрима пословања, науке и струке. Позајмљенице, нарочито терминолошке, природни су део сваког живог језика, а чињеница је да терминологија домена стручне употребе савременог српског језика бележи велико присуство англицизама. С једне стране оно је оправдано - краткоћом и

${ }^{4}$ Закон је доступан на: http://www.paragraf.rs/propisi/zakon_o_standardizaciji.html 
међујезичком транспарентношћу, тј. интернационалношћу (односно њиховом високом фреквенцијом појављивања у великом броју језика), а с друге, опет, неретко јесте одраз жеље за модерним и привидно стручнијим изразом, која је некада обележена и недовољним познавањем енглеског језика (Бугарски (1986), Прћић (2005), Силашки (2012), Милић (2013), Јакић (2014), Одбор за стандардизацију српског језика). Јасно је да стручна термнинологија захтева што већу једноставност и униформност, која се у највећем броју случајева и постиже англицизмима (обично су језички једноставни, а доминантни и свеприсутни захваљујући економској моћи матичних држава). Ипак, процес преузимања страних термина мора бити оправдан, критички, контролисан и спровођен стручно, уз одлично познавање језика-даваоца, а у складу са правилима језика-примаоца, не реметећи притом везу са појмом који означава (тј. суштински је важно очувати му значење). Домаће или одомаћене стручне термине који добро функционишу у пракси никако не треба мењати и прогонити из специјализованог дискурса. У процесу стварања нових термина, треба прво испитати и искористити потенцијал језика о коме се ради, па упоредити домаћу са позајмљеном варијантом, тестирајући првенствено употребљивост терминолошког производа, а онда одабрати адекватно решење.

\section{3. ИНСТРУМЕНТАЛНА СТУДИЈА СЛУЧАЈА: ИСТРАЖИВАЬЕ И АНАЛИЗА СТАВОВА ПРИПАДНИКА ЈЕДНЕ АКАДЕМСКЕ И ПРОФЕСИОНАЛНЕ ЗАЈЕДНИЦЕ У СРБИЈИ}

За потребе анализе идеологија према терминолошкој политици и планирању у Србији, те у циљу идентификације вредновања значаја одређених актера у њеном спровођењу, урађено је емпиријско истраживање ставова једне академске и професионалне делатне заједнице „нелингвиста” према процесу формирања, евалуације и примене термина у професионалном и академском окружењу. Ради се о терминологији менаџмента и ставовима професора и студената Факултета организационих наука Универзитета у Београду према принципима функционисања терминолошке језичке политике у нас.

Реч је о упитнику који је део обимнијег истраживања ставова професионалаца у области менаџмента у вези са терминологијом њихове струке. Методолошки гледано, у питању је комбиновано квантитативно-квалитативно социолингвистичко истраживање, спроведено кроз поступак студије случаја. Сматрамо да је студија случаја инструменталног карактера јер потврђује нашу улазну хипотезу о општим научним и језичким идеологијама и одсуству координације између лингвистике и појединачних струка са једне стране, односно уверења о значају лингвистичких интервенција и институција језичке политике „одозго-надоле” у процесу одлучивања у вези са терминолошким одредницама 
са друге стране. Овде представљено истраживање спроведено је кроз примену кратког упитника полуотвореног типа у коме су учесници могли да се определе за неки од готових понуђених одговора или, пак, да опишу своје ставове о стандардизацији терминологије менаџмента у српском језику:

1. Према Вашем мишљењу, ко треба да се бави стварањем и уређењем терминологије Ваше струке? Уколико Ваш одговор није међу понуђенима, молимо да га допишете.

- Професионална делатна заједница (стручњаци дате струке)

- Језички стручњаци

- Друго:

2. Према Вашем мишљењу, која институција треба да се бави стандардизацијом ${ }^{5}$ терминологије у Србији? Уколоко Ваш одговор није међу понуђенима, молимо да га допишете.

- $\quad$ Институт за стандардизацију Србије

- $\quad$ Одбор за стандардизацију српског језика

- $\quad$ Неки државни орган

- Друго:

Наведена питања постављена су са циљем да се стекне увид у ставове дате академске и професионалне делатне заједнице о томе ко треба да води бригу о термионологији менаџмента и њеној стандардизацији. У истраживању су учествовале две групе испитаника. Прву је чинило 10 испитаника - 5 стручњака из области менаџмента који раде као предавачи на високошколским институцијама и 5 стручњака из исте области који раде ван академске сфере (у компанијама различитог типа). Другу је чинило 40 студената менаџмента, будућих носилаца професије у свим друштвеним сферама (академској, привредној итд.).

\section{1. Ставови академске и професионалне делатне заједнице (менашмент): прва група}

Представници из академске сфере јесу два редовна професора, два доцента и један асистент, а уже научне области којима се баве су менаџмент квалитета и стандардизација, организација пословних система, пословна економија и макроекономија и маркетиншка истраживања. Представници струке

\footnotetext{
${ }^{5}$ Свесне чињенице да је стандардизација само један од аспеката било које корпусне језичке политике и планирања, у упитнику користимо тај термин управо зато што је стандардизација појам јасно препознат и у менаџменту као струци, и појављује се као одредница две значајне институције које, између осталог, треба да се баве и терминолошком језичком политиком: Институт за стандардизацију Србије и Одбор за стандардизацију српског језика.
} 
из ванакадемске сфере долазе из јавних агенција, регулаторних тела, страних компанија, одосно из области индустрије лекова и медицинских средстава, трговине грађевинском хемијом, аутомобилске индустрије, производње и имплементације различитих пројеката из сфере друштвеног живота. Испитаници се налазе на позицијама директора управљања квалитетом, руководиоца оперативних послова, менаџера квалитета и менаџера пројекта, а имају од 4.5 до 15 година радног искуства у струци.

На питање ко треба да се бави стварањем и уређењем терминологије њихове струке, где су им као одговори били понуђени професионална делатна заједница, лингвисти и трећа, отворена опција, 7 испитаника је одабрало прву, 2 другу и 1 трећу опцију.

Слика 1. Ставови академске и професионалне делатне заједнице према креаторима и уређивачима терминологије менаимента

(прво истраживање)

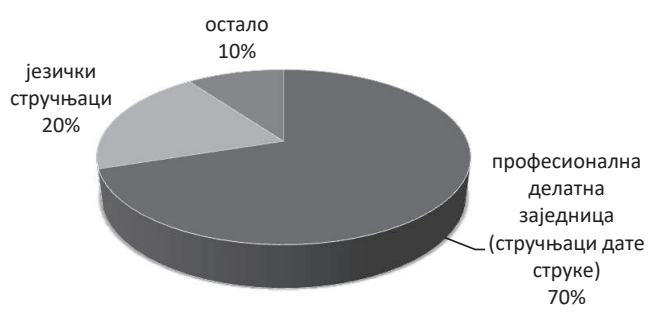

Јасно је да струка жели да она буде творац сопствене терминологије. Дата тежња нешто је израженија код стручњака из неакадемске заједнице који су били део ове групе, него код њихових колега из академског окружења. Испитаник који се определио за опцију „остало” (припада академској сфери) навео је да датом активношћу треба да се баве обе понуђене групе, што је, заправо, илустрација идеје о нужности сарадње лингвиста и професионалних делатних заједница на терминолошким пословима на коју овај рад и жели да укаже.

Упитани да се определе за институцију која би требало да се бави стандардизацијом терминологије у Србији, испитаници дају следећи одговор: 
Слика 2. Ставови академске и професионалне заједнице према одабиру институције која би требало да се бави стандардизаиијом терминологије у Србији (прво истраживање)

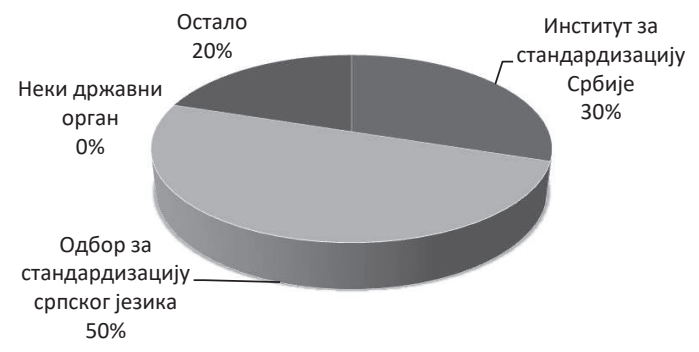

Занимљиво је да, иако већина испитаника сматра да стварањем и уређењем терминологије струке треба да се бави сама професионална делатна заједница (на шта указују одговори на прво питање), 50\% испитаника би посао стандардизације поверило Одбору за стандардизацију српског језика, иако то тело не укључује стручњаке специјализованих области. Три испитаника, односно $30 \%$ њих, определило би се за Институт за стандардизацију Србије, док државним органима нико од учесника истраживања не би дао ово задужење.

Унутрашња статистика дате групе показује да се $60 \%$ испитаника из различитих компанија опредељује за Институт за стандардизацију Србије, а 40\% за Одбор за стандардизацију српског језика као тело које треба да се бави стандардизацијом терминологије. Већина њихових колега из академске сфере (60\%) поверење би дало наведеном Одбору, док остали дају специфичне одговоре.

За опцију „остало” определила су се два испитаника који сматрају да дати посао није ствар једне институције, односно да се ниједна традиционална институције њиме не може делотворно бавити. У овом ставу огледа се препознавање потребе за интердисциплинарним, заједничким и усаглашеним деловањем више појединаца и институција у оквиру области стандардизације терминологије струке, или, пак, стварања нове иституције која би се посветила датом послу и укључила све релевантне стручњаке (слично предлаже Јакић, 2014).

\section{2. Ставови будуће српске професионалне делатне заједнице (менаџмент): друга група}

Другу групу испитаника чинили су припадници будуће професионалне делатне заједнице, односно 40 студената менаџмента. Пошто су у прво истра- 
живање били укључени стручњаци са искуством, како из академске сфере (тј. они који директно усмеравају студенте), тако и они из различитих компанија (који индиректно утичу на студенте), за друго истраживање одабрани су студенти, будући чланови професионалне делатне заједнице и представници струке у свим сферама (академској, привредној итд.). Тачније, у истраживању учествовали су студенти Факултета организационих наука Универзитета у Београду са свих година основних студија и са сва четири студијска програма (Менаџмент, Информациони системи и технологије, Операциони менаџмент, Менаџмент квалитета и стандардизација).

На питање ко треба да се бави стварањем и уређењем терминологије њихове (будуће) струке добијамо следеће одговоре:

Слика 3. Ставови будућих стручњака према креаторима и уређивачима терминологије менаимента (друго истраживање)

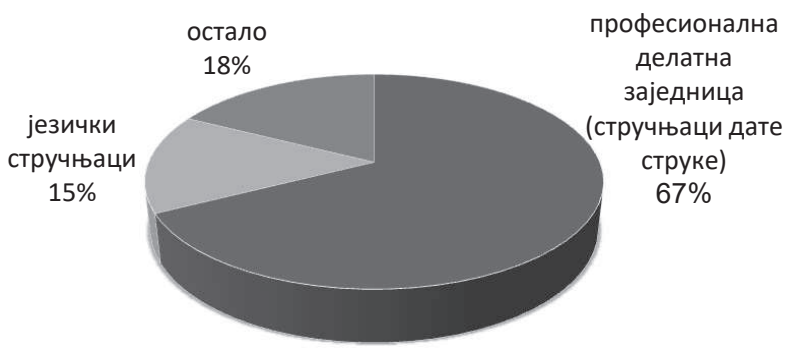

Прецизније, 27 испитаника (67.5\%) сматра да је то задатак професионалне делатне заједнице, 6 испитаника (15\%) мисли да је посао језичких стручњака, а за опцију „остало” одлучује се 7 (17.5\%) испитаника. Под „остало” од 7 одговора 6 износи да терминологијом струке треба да се баве обе наведене групе, док један каже да је реч о послу свих који долазе у контакт с њом (што у се, у једну руку, подудара са преосталим одговорима из групе).

Недвосмислено је да студенти активности на пољу терминологије струке сматрају задатком професионалне делатне заједнице, иако један мањи број испитаника препознаје и потребу за заједничким деловањем струке и лингвиста.

Упитани да се определе за институцију која би требало да се бави стандардизацијом терминологије у Србији, испитаници дају следећи одговор: 
Слика 4. Ставови будуће професионалне делатне заједнице према одабиру институиије која би требало да се бави стандардизаиијом терминологије у Србији (друго истраживање)

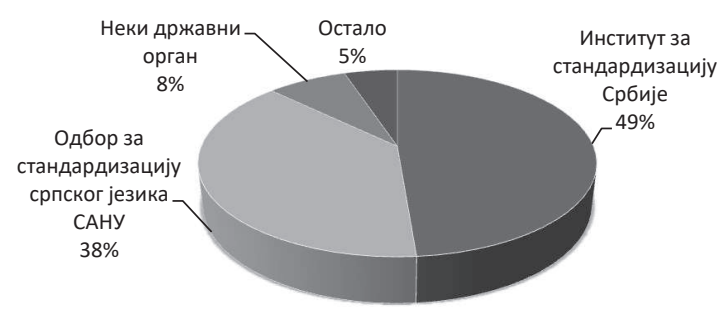

За Институт за стандардизацију Србије опредељује се 19 испитаника (48.7\%), за Одбар за стандардизацију српског језика 15 (38.5\%), за неки држави орган 3 (7.7\%), а за опцију „остало” 2 испитаника (5.1\%). Под „остало” један испитаник наводи стручњаке дате струке и оне који ту терминологију највише користе, а један наводи исто, уз напомену да термини треба да буду јасни не само струци, већ „свима”. Занимљиво је да би неки студенти (иако само $7.7 \%$ њих), за разлику од професора и стручњака ван сфере академије, стандардизацију терминологије поверили неком државном органу.

\section{4. АКТЕРИ КРЕИРАњА ТЕРМИНОЛОШКЕ ЈЕЗИЧКЕ ПОЛИТИКЕ И ПЛАНИРАЮА У СРБИЈИ: ЈЕЗИЧКИ МЕНАЏМЕНТ И ЈЕЗИЧКО ЛИДЕРСТВО}

Као што се јасно види из резултата истраживања, највећи део испитаника из групе већ оформљених стручњака, чије мишљење дели и већина испитаника будућих стручњака (друга група), сматра да терминологијом њихове струке треба да се бави релевантна професионална и академска делатна заједница. Знатно мањи број испитаника верује да је то посао лингвиста. Ипак, код обе групе се кроз отворену опцију изнедрава идеја да је интердисциплинарни приступ терминолошкој политици који би укључивао представнике различитих релевантних научних области и професија опција коју треба озбиљно разрадити.

Јасно је, дакле, да испитивана академска и професионална делатна заједница своје онтолошко и знање изнедрено кроз тврдње жели да преточи у терминолошко знање без обраћања пажње на потребе других делатних заједница са којима неминовно ступа у комуникацију. Проблематичност оваквог става неретко се огледа у лошој одређености термина. Добар пример био би низ одредница управљање квалитетом/ менаимент квалитета 6 контрола

${ }^{6}$ Стручњаци из области менаџмента квалитета инсистирају на генитивној конструкцији у овој терминолошкој синтагми уз образложење да се менаџмент квалитета састоји од планирања, 
квалитета. Енглески термин quality management се у стандарду SRPS ISO 9000: 2015 преводи као управљање квалитетом (3.3.7) и одређује се као „део менаџмента усредсређен на испуњавање захтева за квалитет". Међутим, yправљање је српски термин адекватан енглеском термину control (дакле, quality control = yправљање квалитета) због чега термин менаимент као интернационализам мора да заузме своје место у српској терминологији у овој области (менаимент квалитетауместо управљање квалитета). При томе, Стандард SRPS ISP 9000: 2015 термин quality control преводи као управљање квалитетом, што додаје вишезначности и конфузији при употреби ових термина. Јакић (2014: 102), такође, скреће пажњу на овај чест пропуст. Исти се уочава и у Leksikonu pojmova (2009), где се за превод quality control узима контрола квалитета уместо управљање квалитета.

Заступљен у много мањој мери, али веома релевантан јесте став наших испитаника о потреби за интердисциплинарном сарадњом конкретне професије и лингвистике, који би се могао одредити као деловање језичке политике „одоздо-нагоре” (професионална делатна заједница) и „одозго-надоле” (институције језичке политике, односно лингвисти).

Када је реч о одабиру институције која треба да се бави стандардизацијом терминологије струке, већина испитаника из обе групе опредељује се за Одбор за стандардизацију српског језика, а нешто мањи број за Институт за стандардизацију Србије. Присутно је мишљење да дати задатак није ствар само једне институције, као и да ниједна традиционална институција не може да да делотворно решење.

Посебно је занимљиво запажање да је одговор на друго питање у извесном нескладу са одговором на прво питање. Ако међу припадницима одређене професионалне и академске делатне заједнице преовлада мишљење да терминологију струке треба да ствара и уређује сама струка, зашто би се њена стандардизација поверила Одбору за стандардизацију (који не чине стручњаци специјализованих области и који се бави целокупном језичком стандардизацијом)?

Мишљења смо да је овај став директна последица деловања идеологије стандарднојезичке културе у Србији која намеће идеју да су све интервенције на стандардном језику веома осетљиве не само из структуралистичке већ и друштвенополитичке и културне перспективе (рецимо, питање преузумања интернационализама, пре свега преко енглеског језика, насупрот локализацији термина у социолингвистичким регистрима професија и струка у српском

управљања, побољшавања и обезбеђивања квалитета, те да да сходно томе треба задржати изворну падешку конструкцију и у термину који садржи енглеску позајмљеницу.

${ }^{7}$ Енглески термин који одговара српском термину контрола у области менаџмента квалитета јесте inspection. 
језику). У стандарднојезичким културама језичка политика и планирање стоје у директној вези са језичким менаџментом (енгл. language management), концептом које уводи Сполски (Сполски, 2009), и који се дефинише као „(...) експлицитан и јасно документован напор појединца или групе која сматра да поседује аугоритет да модификује језичку праксу или језичка уверења" (Spolsky, 2009: 5), те се идентификује као језичка политика и планирање „одозго-надоле". У одговорима наших испитаника јасно се огледа став да се питање форми и структура стандардног језика, чак и када се ради о терминологији њима неопходној за недвосмислену и оптимализовану професионалну и академску комуникацију, поверава академским институцијама и институцијама система у оквиру кога језички менаџери имају хијерархијску функцију са које доносе одлуке о употреби језика у јавној сфери (Филиповић, 2015a: 45).

Уколико покушамо да понудимо додатно тумачење ставова мањег броја наших испитаника о потреби интердисциплинарног приступа и сарадње у оквиру терминолошке језичке политике и планирања, можемо увести концепт језичког лидерства (енгл. language leadership, Филиповић, 2015a, 2016, 2017) који је комплементаран језичком менаџменту Сполског. Језичко лидерство се ослања на партнерство, оснаживање, тимски рад, умрежавање и улогу контекста (Вајтли, 2004: 13-14) у коме се пажња посвећује како научним, тако и етичким, моралним и културним принципима било које људске делатности (у нашем случају, у обзир узима различите врсте онтолошких и знања преточено у тврдње, као и дефиницијска и терминолошка знања). Концепт лидерства преузет је из теорије комплексности (Вајтли, 2004; Кира и Ван Ејнатен, 2006, Ул-Бин и др., 2007, Фошер и др., 2008, и др.) и базира се на принципу хетерархијске делатности засноване на међузависности заинтересованих страна, минималном присуству хијерархије, разноврсности интереса и знања, те доброј вољи и поверењу свих учесника (Старк, 2001, Филиповић, 2015a: 37-43).

Управо је такав приступ терминолошкој језичкој политици и планирању у складу са принципима које нуди УНЕСКО (2005). При формирању термина, његовом тестирању, складиштењу, примени и трансферу знања, потребно је увек у виду имати све факторе оквирно наведене у уводном одељку овог рада (онтологије лингвистике и релевантних професија; друштвеноисторијске, политичке и културне факторе: глобализацију, глокализацију, локализацију, утицај енглеског као глобалног језика академске и професионалне комуникације; социолингвистичке и културне факторе: језичке идеологије и когнитивне културне моделе функционисања шире говорне заједнице итд.).

У моделу језичког лидерства које се може применити на све аспекте језичке политике и планирања, па тако и на терминолошку политику, можемо говорити о адаптибилном, омогућавајућем и административном лидерству. Адаптибилно терминолошко лидерство је оно у коме припадници одређене 
професионалне или делатне заједнице уводе нове терминолошке одреднице неопходне за успешну и једнозначну комуникацију. Омогућавајуће терминолошко лидерство већ подразумева интердисциплинарност и хетерархијску сарадњу представника различитих делатних заједница, односно евалуацију једнозначности и комуникацијске вредности термина у дијалогу између професија и научних дисциплина кроз различите врсте терминолошких провера (в., рецимо, Петерс и Брашлер, 2001; Кинг. М. С., М.С. Липски и Л. Шарп, 20028). Административно терминолошко лидерство подразумева активну делатност лингвиста који у сарадњи са осталим дисциплинама и професијама раде на систематизацији и стандардизацији термина професија и наука, у оквиру корпусне језичке политике „одозго- -надоле” и под покровитељством институција система, односно државе, што резултира формирањем једнојезичних и вишејезичних информатичких терминолошких база, меморија и система који се користе за употребу, трансфер и унапређење терминолошких знања.

\section{ЗАКљУЧЦИ}

Терминолошка политика и планирање у овом раду дефинише се као сегмент опште корпусне језичке политике и планирања од пресудне важности за развој језика посебне намене (енгл. language for specific purposes), односно за развој социолингвистичких регистара професија и научних дисциплина. Рад препознаје значај термина̂ као основих значењских елемената у професионалној и академској комуникацији, јер термини представљају језичке реализације појмова и концепата и носиоци су онтолошких знања дате професионалне или научне области. У досадашњој корпусној језичкој политици и планирању у Србији, терминолошка питања директно су се доводила у везу са језичком стандардизацијом, те су, у складу са стандарднојезичком природом нашег когнитивног културног модела, увек сагледавана као одговорност лингвиста, односно језичких планера који се баве језичком политиком „одозго- -надоле”. Међутим, професионална и академска реалност нам указује на чињеницу да у исто време функционише и терминолошка политика „одоздо-нагоре” као неминовност сваког напретка у датој истраживачкој или професионалној области: термини су основни значењски елементи комуникације у оквиру дате професије или научне дисциплине које првенствено користи релевантна делатна заједница, те се терминолошке базе непрестано шире, допуњавају, мењају. Веома често при томе не постоји добра комуникација између онтолошких и

${ }^{8}$ Увидом у наведене чланке јасно се препознаје интердисциплинарна природа терминолошких активности. Први је из области информационих технологија и менаџмента знања, а други из области медицинских наука, али су нам оба била изузетно значајна за дубље разумевање процеса евалуације и примене термина у одређеним професијама. 
знања преточених у тврдње различитих професија или научних дисциплина што резултира вишезначошћу и недовољном транспарентношћу термина у међудисциплинарном и међу-професионалном дијалогу. Обједињујући интердисциплинарна теоријско-методолошка знања о језичкој политици и планирању, терминолошкој језичкој политици и ширим концептима језичког лидерства и менаџмента језика, са једне стране, и резултате инструменталне студије случаја базирне на емпиријском истраживању ставова афирмисаних и будућих стручњака у области менаџмента према терминологији њихове струке (конкретно према питањима субјеката креирања и спровођења терминолошке језичке политике), са друге стране, овај рад нуди нову вишедимензионалну интердисциплинарну хетерархијску перспективу за даљи ефикасан и сврсисходан развој терминологије у српском језику. Сваки развој терминологије треба да се базира на адаптибилном, омогућавајућем и административном терминолошком лидерству, које може допринети већој систематичности и кохерентности у оквиру ове високо динамичне области која захтева континуирану сарадњу и праћење функционисања термина како на интрајезичком плану тако и у вишејезичним професионалним и академским комуникативним ситуацијама.

\section{ЛИТЕРАТУРА}

Витли 2004 (3. издање): М. J. Wheatley, Leadership and the New Science. Discovering Order in a Chaotic World, San Francisco, CA: Berrett-Koehler Publishers Inc.

Ван Дигелен и др. 2004: J. Van Diggelen, R. J. Beun, F. Dignum, R. M. van Eijk \& J-J. Meyer, "Optimal communication vocabularies and heterogeneous ontologies", U R. M. van Eijk, M-P. Huget \& F. Dignum (eds.): Agent communication. International workshop on agent communication (AC) 2004. Revised selected and invited papers. Berlin, Heidelber, New York: Springer, 76-90.

Ул-Бин и др. 2007: M. Uhl-Bien, R. Marion \& B. McKelvey, “Complexity Leadership Theory: Shifting Leadership from the Industrial Age to the Knowledge Era”, The Leadership Quarterly, 18: 298-318.

Фошер и др. 2008: J. B. P. L. Faucher, A M. Everett \& R. Lawson, “A complex adaptive organization under the lens of the LIFE model: The case of Wikipedia”, Paper presented at: The Fourth Organizational Studies Summer Workshop: "Embracing Complexity: Advancing Ecological Understanding in Organization Studies. ” June 5-8, Pissouri, Cyprus, available at: www.egosnet.org/jart/prj3/egosnet/data/uploads/OS_ 2008/W-070.doc, веб страни приступљено 23. септембра 2010. 
Питерс \& Брашлер 2001: C. Peters \& M. Braschler, "European research Letter. Cross-language system evaluation: The CLEF Campaigns", Journal of the American Society for Information Science and Technology, 52 (12): 1067-1072.

Кира \& Ван Ајнатен 2006: M. Kira \& F. M. Van Eijnatten, “Complex work Holarchies", Discussion paper, version 6.4. 6th Annual Meeting of the European Chaos and Complexity in Organizations Network (ECCON), Bergen aan Zee, The Netherlands, October 20-21, 2006.

Бугарски 1986: Ranko Bugarski, Jezik u društvu, Beograd: XX vek.

Бугарски 2003: Ranko Bugarski, Jezici, Beograd: XX vek.

Дензин \& Линколн (ур.) 2005: N. K. Denzin \& Y. S. Lincoln (eds.), The handbook of qualitative research, $3^{\text {rd }}$ edition, Thousand Oaks/London/New Delhi: Sage Publications.

Елкин \& Браун 2012: P. L. Elkin \& S. H. Brown, "Knowledge representation and the logical basis of ontology", in P. L. Elkin (ed.): Terminology and terminological systems, London: Springer Verlag, 11-50.

Јакић 2014: Гордана Д. Јакић, Терминологија организаиионих наука, Београд: Факултет организационих наука.

Кинг, Липски \& Шарп 2002: King, M.S., M. S. Lipsky \& L. Sharp. "Expert agreement in current procedural terminology evaluation and management coding", JAMA Internal medicine, 162: 316-320.

Милић 2013: M. Milić, „Stvaranje, standardizacija i kodifikacija sportske terminologije u srpskom jeziku", u Nadežda Silaški \& Tatjana Đurović (ur.): Aktuelne teme engleskog jezika nauke i struke u Srbiji: tematski zbornik radova, Beograd: Centar za izdavačku delatnost Ekonomskog fakulteta u Beogradu, 79-89.

Милрој 2001: J. Milroy, "Language ideologies and the consequences of standardization", Jurnal of Sociolinguistics, 5 (4), 530-555.

Прћић 2005: Tvrtko Prćić, Engleski u srpskom, Novi Sad: Zmaj.

Силашки 2012: Nadežda Silaški, Srpski jezik u tranziciji: o anglicizmima u ekonomskom registru, Beograd: Centar za izdavačku delatnost Ekonomskog fakulteta.

Сполски 2009: Bernard Spolsky, Language Management, Cambridge: Cambridge University Press.

Старк 2001: David Stark, "Ambiguous assets for uncertain environments: heterarchy in postsocialist firms", in Paul Dimaggio (ed.): The Twenty-First 
Century Firm: changing economic organization in international perspective, Princeton, NJ: Princeton UP., 69-104.

hармас 2005: K. Charmaz, "Grounded theory in the $21^{\text {st }}$ century", in N. K. Denzin \& Y. S. Lincoln, (eds.): The Sage handbook of qualitative research, $3^{\text {rd }}$ edition, Thousand Oaks/London/New Delhi: Sage Publications, 507-535.

Унеско 2005: UNESCO, Guidelines for terminology management, Paris: UNESCO.

Филиповић 2009: Jelena Filipović, Moć reči: Ogledi iz kritičke sociolingvistike, Beograd: Zadužbina Andrejeviă.

Филиповић 2011: Jelena Filipović, "Language policy and planning in standard language cultures - an alternative approach", u Vera Vasić (ed.): Primenjena Lingvistika u čast Ranku Bugarskom. JEZIK U UPOTREBI, Novi Sad: Društvo za primenjenu lingvistiku Srbije, Filozofski fakultet Univerziteta u Novom Sadu, Filološki fakultet Univerziteta u Beogradu, 121-136.

Филиповић 2015a: Jelena Fili, Transdisciplinary approach to language study. The Complexity theory perspective, London: Palgrave Macmillan.

Филиповић 2015б: Jelena Filipović, “Academic publishing from the periphery: English as the international language of scientific publications in humanities and social sciences", Jezici i kulture u vremenu i prostoru IV/2, 367-373.

Филиповић 2016: Jelena Filipović, "Lingvistika i teorija kompleksnosti. jezičko liderstvo kao intergralni deo jezičke politike i planiranja u 21. veku", u S. Gudurić \& M. Stefanović (ur.): Jezici i kulture u vremenu i prostoru V, Novi Sad: Filozofski fakultet Univerziteta u Novom Sadu, 623-636.

Филиповић 2017: Jelena Filipović, „Jezik, standardizacija, standardnojezička kultura i jezička politika i planiranje", Glasnik odjeljenja društvenih nauka, knjiga 23, CANU, 217-231.

Хауген 1959: Einar Haugen, "Planning for a standard language in modern Norway", Anthropological Linguistics, 1(3), 8-21. Reprinted in a revised form (1961) as Language planning in modern Norway. Scandinavian Studies, 33, 68-81. This version was reprinted (1972) The ecology of language. Essays by Einar Haugen (pp. 133-147). Selected and introduced by Anwar S. Dil. Stanford, CA: Stanford University Press. 


\title{
Сајтографија:
}

http://www.isj-sanu.rs/ (сајту приступљено 27.5.2017)

http://www.jezik.org (сајту приступљено 23.5.2017)

http://www.paragraf.rs/propisi/zakon_o_standardizaciji.html (сајту приступљено 5. 9. 2017)

\section{TERMINOLOGY POLICY AND PLANNING IN SERBIA: INTERDISCIPLINARY APPROACH}

\begin{abstract}
Summary
The paper presents results of an instrumental qualitative case study that confirms the relevance of an interdisciplinary, heterarchic approach to the development of terminology policy and planning in Serbia. Introducing the principles of linguistic leadership, the authors offer a new platform for a unique, contemporary and time-based and spatially based process of creating, evaluating, storing and standardizing terms of different professions and scientific disciplines.

Key words: terminological policy and planning, language leadership, language management, adaptive, facilitative and administrative terminology leadership

Jelena M. Filipović

Andrijana S. Đordan
\end{abstract}

